\title{
The Hidden Life of the Historical System of Rural Roads in a Sector of the Guadarrama Mountains, Central Spain
}

\author{
Ángel Paniagua \\ Consejo Superior de Investigaciones Científicas CSIC, Madrid, Spain \\ Email: angel.paniagua@csic.es
}

How to cite this paper: Paniagua, Á. (2020). The Hidden Life of the Historical System of Rural Roads in a Sector of the Guadarrama Mountains, Central Spain. Advances in Applied Sociology, 10, 257-277.

https://doi.org/10.4236/aasoci.2020.107016

Received: June 29, 2020

Accepted: July 19, 2020

Published: July 22, 2020

Copyright $\odot 2020$ by author(s) and Scientific Research Publishing Inc. This work is licensed under the Creative Commons Attribution International License (CC BY 4.0).

http://creativecommons.org/licenses/by/4.0/

\section{(c) (i) Open Access}

\begin{abstract}
Historical geography has had as a preferred area of study of rural landscapes and societies in the past. In the context of the new rural geography, a road system is analyzed and its historical evolution is used as the source to make a narrative interpretation of the landscape. This narrative interpretation is understood as the evolutionary expression of different values, traditions, actions and hopes of the inhabitants of the area in the course of history. From this perspective, the paths can be used to establish an adequate continuity between the past and the present. The methodology combines the use of cartography, territorial recognition and in-depth surveys. The case study is a sector of the Sierra de Guadarrama located in central Spain.
\end{abstract}

\section{Keywords}

Rural Roads, Narrative Interpretation, Landscape, Past, Historical Geography, Spain

\section{Introduction}

To a large extent, historical geography has had rural areas and societies as an object of study. Thus, rural historical studies have focused on the historical evolution of the landscape and the continuity and resistance of rural landscapes to the processes of change in modern societies (Duffy, 2009). In this context, research on rural roads can have multiple perspectives. It is possible to approach it from rural, cultural or historical geography (Paniagua, 2017). As Strohmayer (2014) suggests, the historical geography is an open field, an amalgamation of traditions. From this point of view, rural roads would be an element of the his- 
torical landscapes that are formed on heterogeneous and multilayered bases. The deconstruction of historical landscapes offers the possibility of analyzing local historical paths in context. Geography has a long tradition in the narrative explanation of landscape characteristics, both as individual elements, or as parts of a complex and dynamic ensemble. In the present contribution we want to approach the analysis of rural roads as an intersection of diverse geographical traditions, which serves as an interpretive framework for their complex evolution up to the present. The case study is the local road system of the La Najarra massif in the Guadarrama Mountains in Madrid province (Spain).

The reason and the meaning of this contribution are framed in the advance of rural studies that seek to reunite the past with the present, analyzing landscapes hidden by changes in the human use of space.

\section{Theoretical Approach: Rural Routes and Geography}

Adopting geographical history over the historical geography (Baker, 2003) as a starting point implies the connection of different academic traditions in the context of new geographical history, for the analysis of place or local paths. The complexity of this perspective allows us to associate and adapt various conceptual points of view in the study of landscapes biographies (Lorimer, 2015) in the form of spatial histories (Baker, 2003) of rural routes. A path expresses the different values, intentions and actions of local inhabitants throughout history (Clark, 1997), by generating imagined worlds of the past (Johnston, 1983). These stories would establish the continuity between past and present (Massey, 1995). With this dimension it is possible to analyze the cultural meaning of historical survival in rural routes and its spatial dimension in history in different scales-from national to local. The path is movement, transit, while the context is fixed; it is linked to the landscape, to the materiality of the space. The absence of movement on the historical trails generates shady landscapes. This duality between materiality and use/immateriality means that roads never have a static character (Riesenweber, 2008). On the contrary, they would have a fluid content resulting from the association of material and everyday life ideas and dimensions (Schein, 2010) in the form of environmental histories of hybrid landscapes, where the most material dimensions and the non-representational geographies are found. The roads and landscapes would be life worlds (Kolen \& Renes, 2015). The life of the historical trails would be associated with both its representation and its use (Paniagua, 2017).

Research on rural roads can contribute to the analysis of the macro and micro dynamics of rural change (Clark, 1997) and how the past contributes, resists, and accommodates to rural transformation processes (Wheeler, 2017). They are also useful for introducing yourself to the complexity of rural processes (Clark, 1997). The evolution of the road system has three stages and two processes of rural change: 1) Traditional stage, in which the road system is configured and expanded, with a dedication to agriculture and a functional use of space. The local 
dimension predominates in the management of the road system and conservation is carried out by the community. In geographic theory this stage has been characterized as pastoral, associated with a nostalgic vision of the past (Cloke, 2016). 2) Modernist stage, where dedication is forestry and traditional agrarian activities are abandoned. The road system falls into disuse and is forgotten, but it is preserved by the characteristics of the repopulation that prevents the growth of undergrowth. The end of the traditional period and the afforestation of the area generate a rural landscape in the shade made up of roads, fences, sheepfolds, cabins, sheepfolds. This stage has been linked in geographic literature with the urban progress of modernity. Rural heritage begins to acquire a relevant and emblematic role in response to modernity (Cloke, 2016). 3) Postmodern stage, in which the area begins to have a natural, cultural and heritage value and the multiple use of space (forest), begins: recreational-sports (hiking), cultural, conservationist (Post, 2013). The value of materiality is fixed and decision making begins to be local, extra local or even global. Multiple uses start the process of alteration-modification-destruction of trails, since conservation is public but usually non-existent. The deterioration generates possible conflicts between: 1) livestock and recreational uses and 2) between more conservative recreational uses (hiking) or other more aggressive uses (mountain biking) for the trail system. Conservation is associated with non-use and non-knowledge and a certain environmental essentialism. The aesthetic dimension appears in this last phase as an expression of a nostalgic point of view of the community and traditional space through the material legacy of local traditional paths (Brady, 2006).

In any case, the perception of the value of roads depends on each country, region and even on each municipality (Taylor, 2013), which influences their interpretation and even their use. They would have a value as a cultural heritage material associated with their economic commodification and an intangible cultural heritage or living heritage associated with the narratives of identity and the use of the past in the present (Whelan, 2014).

\section{Research Methodology and Sources of Information}

All rural cultural landscapes have a local expression (Schein, 2010; Sauer, 1941; Ansola, 2018; Swaffield \& Primdahl, 2014). The historical reconstruction to date of local rural trails suggested their interpretation in a particular context (Hardy, 1988, Wheeler, 2017). As Clark (1997) states, the cultural turn in rural and historical geography benefits the micro-scale level of study.

\subsection{The Choice of the Case Study}

The rural road system is located mainly in the municipality of Miraflores of the Sierra, but it also has continuity in those of Soto of Real and Manzanares of the Sierra, municipalities where the southern orientation of the Najarra massif is found (Figure 1). The Najarra is a place-name of medieval origin, linked to the repopulation of the lands of Segovia in the 11th century, which describes a gentle 


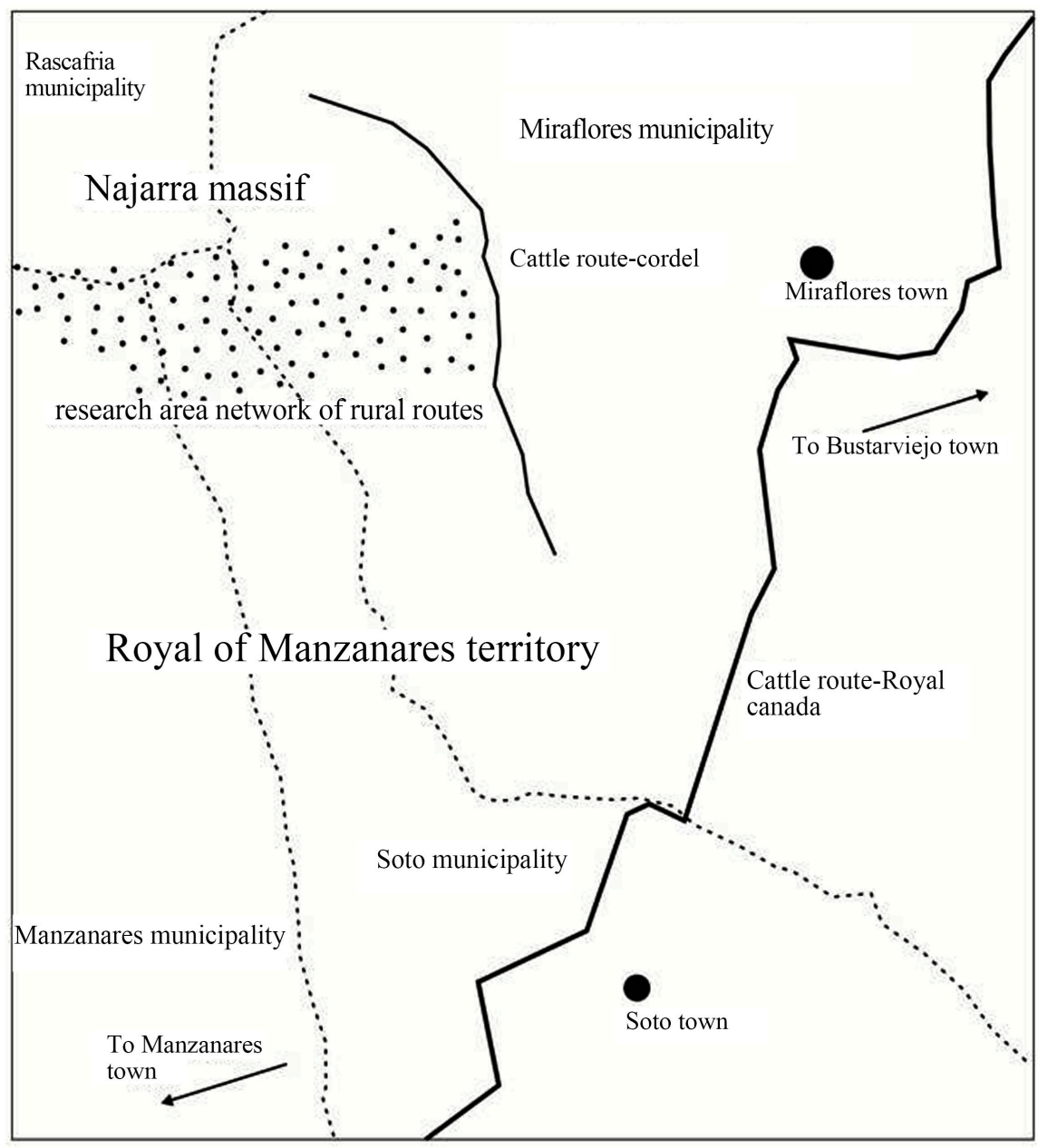

Figure 1. Research area.

descent from a height of over two thousand meters down a gently sloping slope in a sector of the Guadarrama mountains in the area of the Long Rope called the "Espaldar of the Najarra", up to one thousand six hundred meters (Figure 1). The "discovery" of the road system in the Najarra massif was accidental, while hiking the area I walked along abandoned trails without any kind of beaconing. For several years (mainly 2015 to 2017), I dedicated myself to walking and fully knowing the road network, until I was certain that it was a complex and structured system, perfectly preserved having respected (and hidden) the afforestation, its layout and structure (Figure 2). Field work has already been pointed out as an essential element in studies of historical geography associated with particular places (Butlin, 1993). Perhaps it was even used for planting. A road network close to a perfectly structured metropolitan urban area that was not adequately dated and represented. Its use and traditional knowledge died out when the pastoral use ended and it was fossilized with the subsequent reforestation. At this time I thought that a more systematic investigation of the documentary sources of information on the area was needed: archival sources and documentation, historical aerial cartographic and photographic revision. 

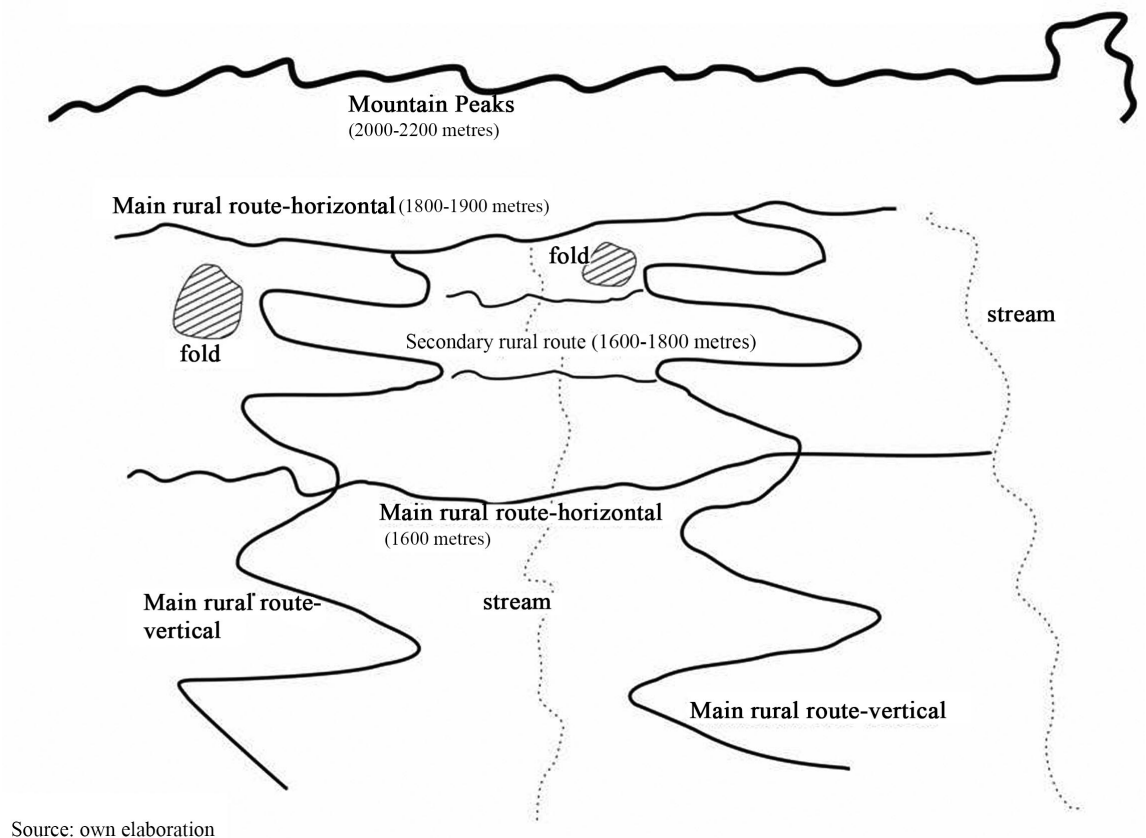

Figure 2. Scheme of the system of rural routes of the Najarra massif, Guadarrama Mountains.

\subsection{Research Sources}

Usually there is a notable contrast between the historical documentation on the Mesta roads and the practically nonexistent one of neighboring horseshoe roads (Paniagua, 2017). In the municipalities where a Mesta path runs, the documentation on it is remarkable compared to the documentation available on the other paths. It is possible to date many local roads "in relation to" the Mesta roads. Thus, for example in Miraflores of the Sierra it is pointed out "that in many places statutes are made against the law and laws of the Reyno" (Laws of the Mesta, 1609. ARCM, box 7. Miraflores de la Sierra Fund), which generate conflicts, but they allow indirectly dating the way. Also, on occasions, the neighboring historical roads have a relationship with the Mesta roads. This is the case of the Najarra road system, which is related to the cord and the Mesta gorge that run through the municipality and to the livestock occupation of the long rope slope for livestock use. The road system allowed to travel all over the slope, at different heights, without descending to the foothills. In any case, although the origin of the roads may have an origin associated with the rural community and the common use of the forest, in the case of the Najarra road network it is an organized and hierarchical system linked to the movement of livestock local and transhumant and to the Cañada Real Segoviana.

Archival and documentary sources have not established the process of creation-or a precise dating-of the neighborhood road system in the Najarra massif, but it has allowed us to specify the geographical and historical context. The documentation of the local archive, currently deposited in the Regional Archive of the Community of Madrid (RACM), the documentation on the creation of the municipality and the initial organization of the space deposited in the National 
Library of Spain (BN), and the documentation have been consulted de la Mesta referring to the municipality in the National Historical Archive of Spain (AHN). With these documentary sources it is possible to establish the process of creation of the municipality, the relations with the neighboring towns, the socioeconomic and territorial organization of the farmers of the municipality and their influence with local life, the conflicts related to the cattle trails of the Mesta (Cordel towards the port of Morcuera and Cañada Real Segoviana) in the form of permanent or occasional occupations by farmers, unauthorized closings ... and, finally, conflicts over the use of communal land-almost the entire Najarra massif -for proprietary uses authorized to favor farmers or livestocks in any municipality with respect to other neighboring municipalities. All this information makes it possible to date "in relation to" the livestock organization of the space -the majadas, flock field-the Najarra road network. Also possible conflicts in its use, which could reproduce those existing in the network of neighborhood roads. Consequently, it is possible to interpret that the road network was drawn with the socioeconomic organization of the space for livestock use. In short, it is possible to establish the context of the creation of the road system.

The field work has consisted of reviewing the historical cartography to verify the absence of the representation of the roads in the Najarra massif or its notable inaccuracy. Only the Cartographic Minute of the National Topographic Map on sheet 509-Torrelaguna made in 1960 (Figure 3) and the cartography of the Autonomous Community of Madrid (ACM) of the year 1988-scale 1: 5000 (Figure 4 and Figure 5) appreciate this road system in an inaccurate and incomplete way. In the rest of the historical cartography it is not reflected. The historical photograph (American flights of the years 1945-46 and 1956-57 preserved in the digital photo library of the National Geographic Institute) prior to the large repopulations in the area, allows to verify the main trails and the existence of a connected network.

The main source of research has been the continuous visit to the area to know and walk in a systematic way the road network of the Najarra massif (Figures 3-5). Reforestation has contributed to the conservation of this road network but has also hidden it. The trail of roads has been followed through small subsidence, alignments, leveling, and separations in the pine plantation ..., with two purposes: 1) to establish continuity and connectivity between the trails that tried to answer the questions' where will it end? "or" where it will lead "in the form of a progressive ordering of reality" where the researcher's impressions and sensations generate a sequential experience (Edensor, 2000: p. 102; Waitt, Gill, \& Head, 2009) that unite the human and the non-human world. In this sense "walking is conceptualized as a territorializing practice forging experiential and intimate knowledge of natural world, this offers possibilities to examine how boundaries between the human and non-human worlds become more or less resilient" (Waitt, Gill, \& Head, 2009: p. 56). In this way, the study tried to move from the traditional studies on walks as the products of place of walks as an ordinary feature of everyday life in the context of cultural to emotional geographies (Lorimer, 2011). 


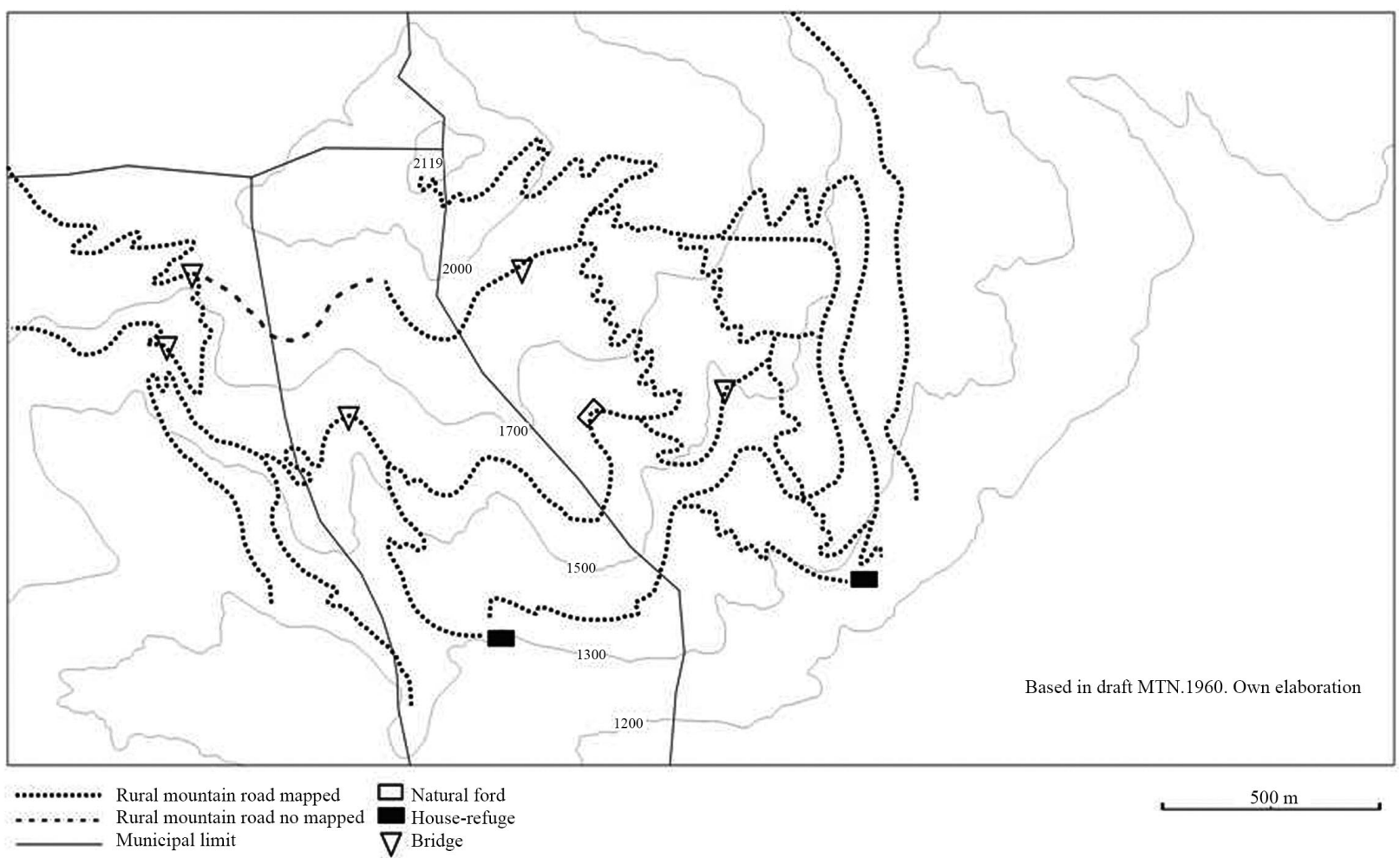

Figure 3. Rural routes in the Najarra massif, 1960.

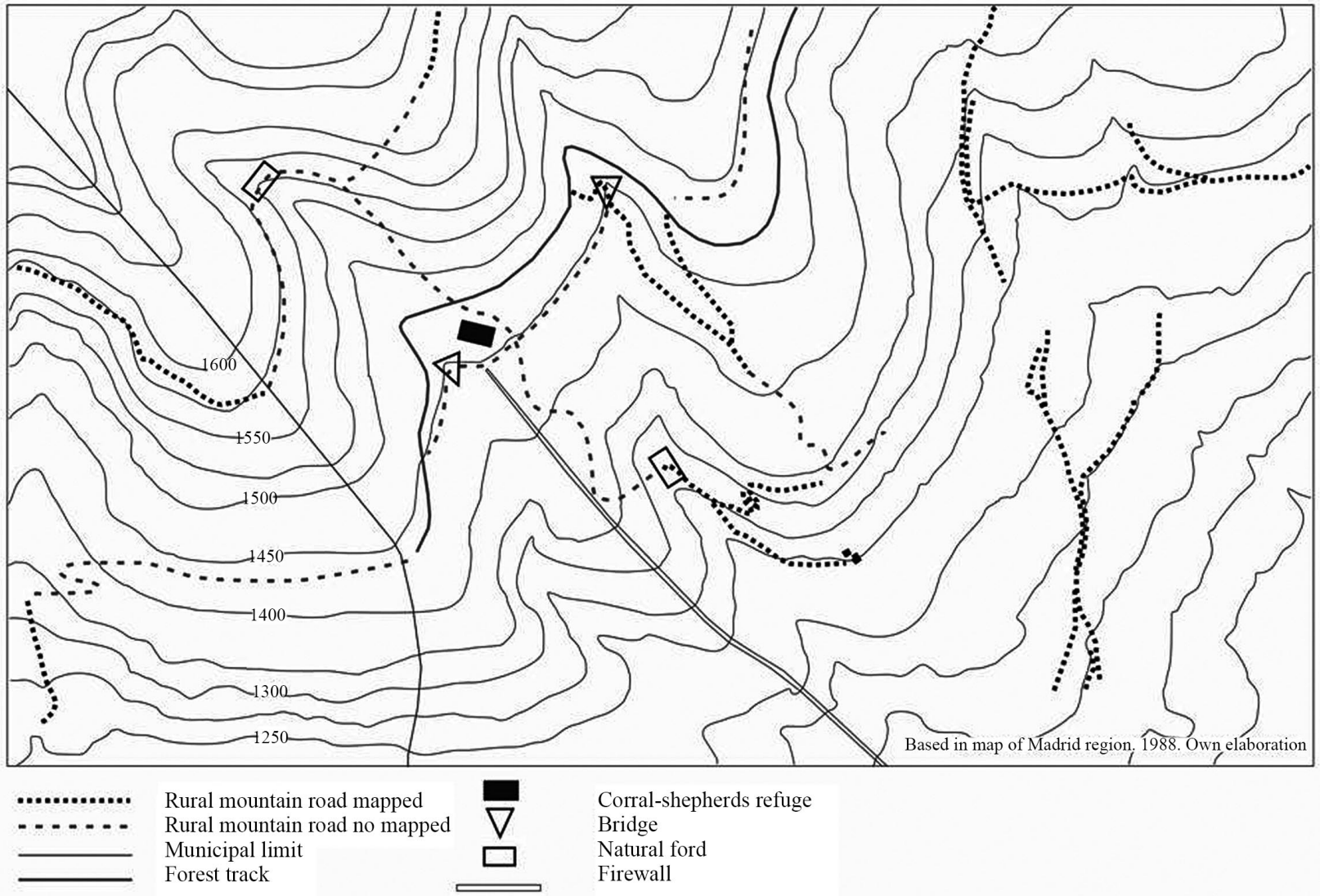

Figure 4. Rural routes in the central sector of Najarra massif, 1988 (Between the limits Miraflores and Soto). 

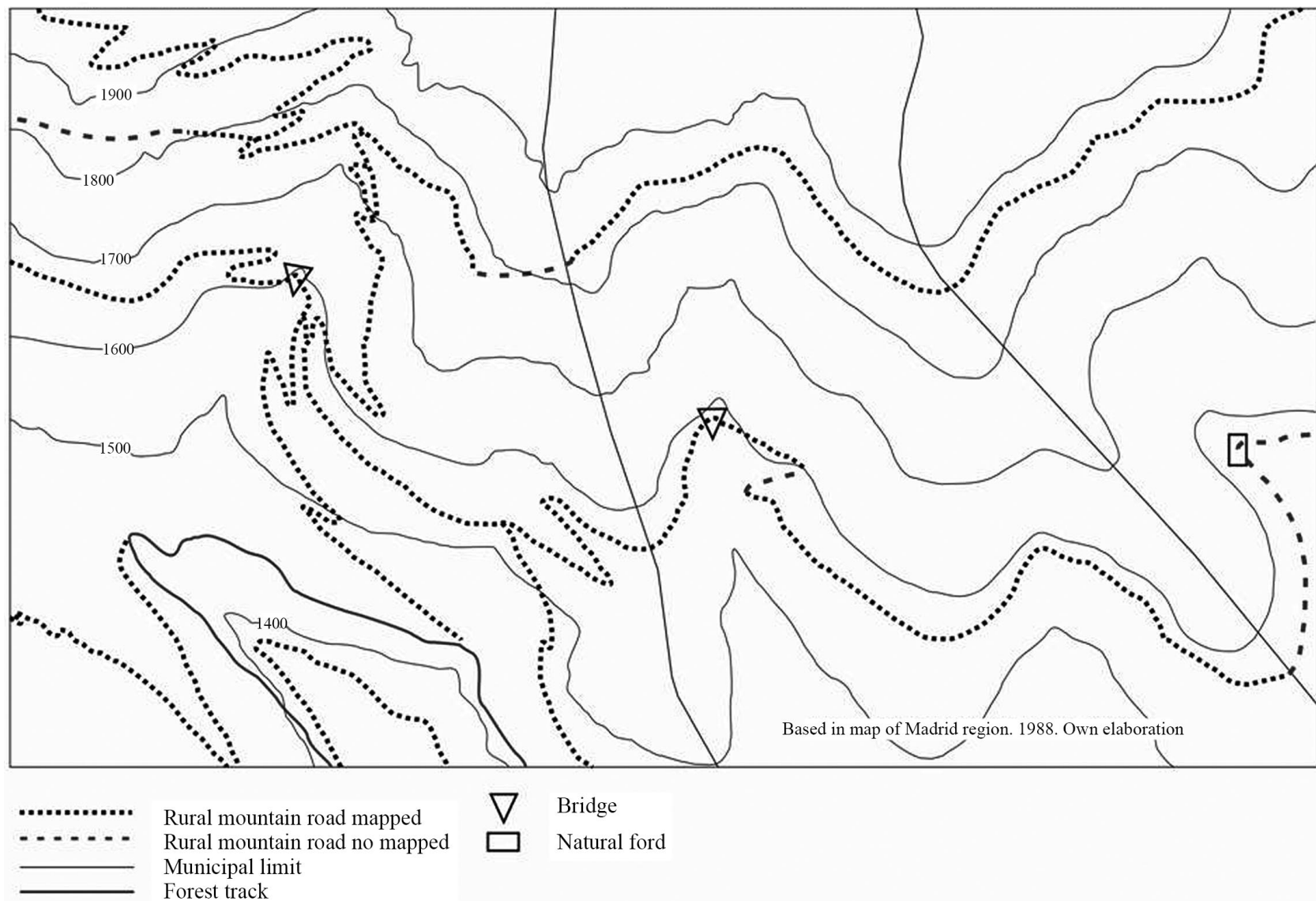

Figure 5. Rural routes in the west sector of Najarra massif, 1988 (Between the limits of Manzanares, Soto and Miraflores).

In the global context of contemporary landscape practices as a research strategy (Rose \& Wylie, 2011). In this perspective, as Price (2016) suggest, walking generates a particular experience of place, a peripatetic sense of place or as MacFarlane (2017: p. 36) indicates: “The path not only seduces the physical eye, but also that of the imagination, that he can only continue the trajectory of the line that he sees in time, towards the history of the path and of those who have used it". Research on historical paths generates an intimate relationship between self and place. 2) Establish connectivity and continuity between flocks. Multiple days in the area over several years have made it possible to understand and connect the entire road network and establish its continuity or, where appropriate, discontinuity due to the deterioration of the terrain in the form of small erosive processes that have altered the leveling of the trail or the opening of forest tracks. The sets or systems of roads express the stresses in their development and an affective atmosphere (Merriman \& Jones, 2017). The transformations due to afforestation and the opening of a dirt track to manage the forest promptly alter the continuity of the previous network of trails, but generate a traditional rural landscape in the shade. This analysis has been completed with five interviews aimed at old livestock's in the area during the spring of 2019, to specify the socio-territorial context of abandoning the trails. 


\subsection{Research Process}

The research process has four main phases: 1) the research has had a long process of field research, exceeding five years. Of these three very intensive-between 2015 and 2017-in a field work on the trails in the study area. It has been an experimental investigation by the researcher, about his own experiences on the trails. Firstly, the network of trails was explored to check if there was an articulation and connectivity between the different trails. Once it was verified that it really constituted a road system, its route was systematized, in order to check its condition in all its extension. 2) In parallel, its (non) representation and its weaknesses were verified in the historical cartography. This allowed to affirm the hidden character of the road system due to its cartographic forgetfulness. 3) Subsequently, an investigation was carried out in the historical, regional and national archives to frame its historical evolution and relevance. Also to establish an approximate dating. 4) Finally, a series of interviews with elderly ranchers were conducted to frame the process of loss of traditional use of the trails and the current problems.

\section{Roads}

\subsection{The Occupation of Space}

For more than three centuries, between the 8th and 11th centuries, the Guadarrama Mountanis was the border between the Christian and the Muslim world. The council of Segovia had colonized the area since the time of King Alfonso X, occupying the entire Real de Manzanares-with Segovian ranchers who settle on small plots of land and form villages' (Colmenarejo et al., 2012: p. 191), the germ of the current towns-the municipalities of Manzanares, Soto and Miraflores (Figure 1). Other sources indicate that they were Basque people from the ancient kingdom of Navarra (Menéndez Pidal, 1960). Starting in the 11th century, with the movement towards the Tagus of the border between the Christian and Muslim world, the Sierra de Guadarrama began to be settled in a stable way and a system of roads was established (Vías, 2001: p. 31). But banditry must have been frequent until the fifteenth century. After this period, Miraflores of the Sierra was a border territory between the lands of Segovia and Madrid. The foundation of Porquerizas-current Miraflores of the Sierra-is quoted by certain authors between 1240 and 1250 (Apuntes, 1933). Fernández Ibero (1953) places in 1228 the creation of the town by King Alfonso X, along with other towns, coinciding with the occupation of the territory to the south of Guadarrama Mountains called The Real of Manzanares. Other authors place it in 1268 during the reign of Alfonso X (González Guadalix, 1994). There are authors who indicate that its foundation coincides with real support for the Mesta (Fernández Suarez, 1995: p. 52). The origin of the town is pastoral, from Segovians who grazed their cattle on these lands and their flocks. From 1383 it belongs to the Casa of Infantado, for a period of four hundred years, until in 1811 the Assemblies of Cádiz promulgated that all the manors were incorporated into the nation (Fernández Ibero, 1953: p. 37). During this time the summits of the Najarra massif constituted the limits 
between the lands of Segovia and those that were part of the possessions of the Duke of Infantado (Vías, 2001: p. 187).

\subsection{Conflicts and Construction of Space}

Since the beginning of the 14th century, the occupation of the territory has adopted a more organized structure (Asenjo, 1986). The first ordinances were approved in 1419, they indicate that "people lived in part of agriculture, dedicated to the cultivation of orchards, vineyards, some cereal and their meadows for livestock" (González Guadalix, 1994: p. 38). An economy that has subsisted in the town until recently. In $1750,88 \%$ of the population was engaged in agriculture and livestock (Nieto, 2017). Livestock farming is an essential element, especially the merino sheep, in the formation of the local social structure and in the regular relationship of the forest with livestock (Nieto, 2017). Since this time there have been numerous lawsuits for boundaries and land rights between residents of different towns. An example is the dispute at the Garganta site, delimited by the jurisdiction of Manzanares of Real, in order to forbid the entry of livestock from other towns, when traditionally it had been a place of enjoyment and use of the common (Presidency of the General Livestock Association, November 15, 1839. ARCM, box 8_8.1. Miraflores of the Sierra Fund). This complaint or dispute between municipalities for land boundaries of the common of several towns (in the territory of Real of Manzanares) for the exclusive use of only one, was something common in the mid-nineteenth century (Orders on the Mesta of the intrusions of the strings Years 1847-50 and 51, and 52. ARCM, box 8, 8.3. Miraflores of the Sierra Fund). This also occurred in the pastures of the Bustarviejo valley, with conflicts over occupations by the Miraflores council. In the summit areas there do not seem to be conflicts over pasture use. Since the 17th century, agreements have been made for the grassland community, excluding the municipal pastures, between the municipalities around The Najarra, a situation that was maintained in the 18th century coinciding with the sale of vacant land (Colmenarejo et al., 2012: p. 160).

\subsection{Livestock Roads, Disputes and Organization of the Uses of Rural Space}

The difficulty of communications was an essential element in Miraflores of the Sierra from its foundation, although from the beginning they were grow thick places and passengers "and there were many people on the road" of remote origin. In other words, it was a place traveled by strangers and of a certain population entity. It was tiring and difficult to go/come from the town of Manzanares of Real to carry out administrative and civil procedures, as they were "remote places". It is deduced that the state of the communications between the towns was deficient, which presupposes a precarious or non-existent neighborhood road network. The distance or spatial apartment is one of the main reasons that are argued to grant the villazgo to Miraflores of the Sierra along with the recognition of tax advantages, the right to impart justice and the privilege to the 
mayors to hear lawsuits in villas and populated or depopulated terms of its municipal scope (National Library, 1524a and b, 1607). The right of town supposed less displacements and greater municipal autonomy. It also facilitated a more autonomous and dynamic occupation of the territory. During the XV century the use of the municipal pasture land was regulated and the agrarian occupation of the municipality was organized (Fernández Ibero, 1953). This process of adherence lasts until today and aims to protect the pasture lands closest to the town from foreign cattle. The rest of the municipal term remains free of proprietary markings in the form of walls and walls. The farms were divided according to natural markers such as roads, sidewalks, streams or landmarks (Fernández Suarez, 1995). There was a community of pastures based on harmony in all areas of the Real de Manzanares, with the exception of the pasture.

The road system in Miraflores is closely related to the proximity to the Cañada Real Segoviana. From the 13th century onwards, with the Reales Cédulas of the Mesta, it has undergone a remarkable development (Fernández Suarez, 1995). From the 12th century to the present day, it is the largest communication route in the municipality. As it passes through it, it has ramifications throughout the municipal space. On the other hand, the existence of this important cattle trail contributes to strengthening the remarkable relations between the municipality and Mesta itself or the National Cattlemen's Association. In Miraflores there was a gang of cattle livestock's from The Mesta, made up of residents of the town. Every year a Mesta Gang Board was established that established the “... enrollment of transhumant, transmitting cattle and shelves with distinction of species that counted in the style of a cabin there have been in this Miraflores of the Sierra gang in the current year (...) according to the relationships that each of their ranchers has given ..." (Gang Boards, Registration, appointments. Different years, registration in 1891. ARCM, box 8, Miraflores of the Sierra Fund). In 1795, it brought together 58 livestocks from Miraflores; in 1815, 49 from Miraflores, 8 from Chozas (Soto of Real) and 6 from Manzanares of Real; in 1819, 68 from Miraflores, 12 from Chozas and 18 from Manzanares; in 1845 it brought together 49 livestocks from Miraflores, and 7 from Manzanares (Orders on the Mesta gang-various years-ARCM, box 8, Miraflores de la Sierra Fund). They were mainly owners of wool and goat cattle at the beginning of the 19th century, although there were also ranchers who combined wool and goat cattle with other types of cattle in the middle of the 19th century. Every year he chose his positions: mayor, prosecutor. ... But, what is relevant is that the local ranchers saw in La Mesta and in this organization a great possibility of protecting their interests (Fernández Suarez, 1995-author who indicates that the crews did not usually pass of 30 Miraflores livestocks), in relation to the confrontation with other neighboring farmers. The crew collaborated with the municipality in the protection of roads, streams and troughs, closely related to livestock life and in possible usurpations or invasions.

Already in the year 1796, a transhumant livestock of recognized trade and some roots was appointed by the council, with at least 500 head of cattle-or 
another livestock in default-to serve as prosecutor and represent the council in the hearings (Royal Document of SM and Gentlemen of the Council, 1796, ARCM, box 7, Miraflores of the Sierra Fund). Every spring a list of complaints was made and once a year a recognition was made of "if pastures, steps, canyons, strings, resting places and watering holes, are or are not free and free for the transit of livestock (...) and they will protect the defense of the owners of the cattle, and shepherds who come with just complaint" (Royal Document of SM and Council Lords, 1796, ARCM, Box 7, Miraflores of the Sierra Fund). In common pastures "foreign livestock of all kinds cannot be prevented from grazing when they transit from one term to another or from one province to another" (Ordinances, accounts and matters of the Mesta. Compilation of documents, 1724-1728. ARCM, boxes 8.6 and 8.7. Miraflores of the Sierra Fund).

The existence of notable and extensive documentation on the duty to respect livestock routes in the municipality by farmers and livestock's, reflects a certain pressure for the use of rural areas. Also the existence of conflicts over the use of land. Already from the beginning of the 17th century it was evident that, according to the laws of the Mesta, their transhumant cattle must have flowed through its glens, even "when the pasture was occupied" by herbaceous and woody crops or by pastures and closed orchards (General laws of the Mesta-annotations in the margin and underlined-1609, ARCM, box 7, Miraflores of the Sierra Fund). This is confirmed by the order of June 21, 1824 to till and sow in year and time leaves so that tillage and livestock "prosper together" (Order of June 21, 1824, ARCM, box 7, Miraflores of the Sierra Fund). As well as the various writings of the years 1823 and 1824 on the obligation to respect the livestock routes used by cattle in transhumance or so that the canyons, twine, sidewalks, transits, resting places and watering holes of the cattle of the Royal Cabin are open. Thus a document of November 28,1823, addressed to the Subdelegate of the Mesta of Miraflores of the Sierra claims that "forgetting or disregarding the same authorities for the laws that particularly entrust them with the protection and protection that they must grant to the said pastors and won in the transhumation" (Writings of November 28, 1823 and June 18, 1824, addressed to the deputy delegate of the Miraflores of the Sierra party, ARCM, box 7, Miraflores of the Sierra Fund). This situation continued in the last third of the 19th century and the beginning of the 20th. There are numerous writings from the municipal visitor of the National Cattlemen's Association (successor organization to the Mesta) indicating that the ravine on its way through Miraflores of the Sierra had numerous intrusions and breakages and that cattle farmers are required to be "happy" to allow them passage of their cattle in these servitudes. The municipality is urged to correct such abuses with the ranchers and to be informed of the true state of the easements and proceed to their demarcation (Miraflores of the Sierra. Madrid. 1881. AHN. Diverse-Mesta, 885, exp. 3). Specifically, an intrusion of half of the Segovian ravine on a 120-meter section in 1906 in the The Colladitos area is cited. Also of alterations in 1863 in the system of roads and landmarks with easements for the cattlemen linked to the Colada from which the road 
system of The Najarra starts (Miraflores of the Sierra. Madrid. 1881. AHN. Diverse-Mesta, 885, exp. 3) (Figure 1).

But, in short, still in the 19th century the municipality must have been a largely unexplored territory. As Lorenzana indicated in 1785 (collected by González Guadalix, 1994: pp. 89-90): "he is the most unhappy and lanky of the peoples, located in extremely fertile soil".

During the Republic, in the 20th century, the new highway that leaves Miraflores opens and ends in Rascafría (Figure 1) (López, 2002: p. 130). Until that date, according to the map of Coello (1845-50), there were two routes that communicated Madrid and Rascafría-El Paular, one direct through Soto of Real and the other through Porquerizas (now Miraflores of the Sierra). On the other hand, in this area there are numerous itineraries, some very old mentioned in the book of the Montería of Alfonso XI in the Middle Ages and others in the maps of Coello in the 19th century (López, 2002: p. 130).

In the contemporary municipal planning specific conditions of the undeveloped land of special protection for its forest interest are established. Specifically, the opening of roadways other than those of exclusive forest interest for the maintenance and exploitation of these areas is prohibited, seeking to use the edges of the exploitation as firewalls. In turn, specific conditions of undeveloped land with special protection for their livestock interest are also established. Specifically, the topographic alteration of the land is prohibited by widening or new opening of roads, earthworks or spills, which are not forced by the exploitation of the land, by the actions and plans approved by the public administration (Consejería de Política Territorial, 1987). There are no explicit references to the preservation of local historical roads.

\section{The Road System of the Najarra Massif}

The Najarra is a toponym of medieval origin, linked to the repopulation of the lands of Segovia in the 11th century. The repopulation of this area was carried out "by Basque people from the kingdom of Navarra who came from the eleventh century to repopulate the Lands of Segovia and who, with the name of Navarrese, Nafarros, Narros or Naharros, left so many similar place names in the fields, mountains and villages at the ends of Castilla" (Menéndez Pidal, 1960).

The Najarra road system is a complex and hierarchical system of bridleways that aims to access the entire southern slope of the Najarra massif between the municipalities of Miraflores de la Sierra, Soto de Real and Manzanares de la Sierra (Figure 1 and Figure 2). A system of zig-zag roads connected to each other, topped at their lowest and highest elevation by horizontal paths (Figure 2). The connection of sheepfolds from 1200 meters (pastures-oak grove) to 1900 meters (high mountains) on headlands constitutes an exhaustive system of use of the slope, completely adapted to the orography. When constituting a structured system of roads, it requires knowledge of the topography and the mountain uses that are to be connected, especially the sheepfolds. There was a system of life on 
the slopes of the Najarra. The end of the road system is mobility through the mountains and between the various flocks, without the need to descend into the space occupied by the meadows. It is a complex system given that it has higher capacity routes, intermediate routes and shorter routes. It constitutes a planned design of the occupation of the mountain by man. All the flocks have two or three connection paths that make up a complex network of up-down or lateral displacement (Figure 2). This plot of roads obeys an organization of the space with three dimensions: physical, socioeconomic and legal. The physical organization tries to connect flocks through roads, the socio-economic organization organizes the space through gangs that take care of the livestock and the legal organization is based on the division of rights.

The road network covers an extensive area of $9.64 \mathrm{~km}^{2}$, on the southern slope of The Najarra, $3.62 \mathrm{~km}^{2}$ in the municipality of Manzanares of Real, $2.39 \mathrm{~km}$ in Soto and $3.63 \mathrm{~km}$ in Miraflores (Figure 3), the total road network has an approximate length of 39 kilometers $(38.97 \mathrm{~km})$ distributed in $12.18 \mathrm{~km}$ in Manzanares, $9.25 \mathrm{~km}$ in Soto and $17.54 \mathrm{~km}$ in Miraflores (Figures 3-5). The slope ranges from $0 \%-5 \%$ on the roads that contact the system and that follow contour lines, $14 \%-18 \%$ of the roads that go up in wide zig-zags and $23 \%-30 \%$ of the roads that ascend by small zig-zags at the top of the mountain or small trails that cut perpendicular up the mountain. The trails with the lowest slope are usually wider and those with a steeper slope, those with $0 \%-5 \%$, depend on whether they connect zig-zag, where they are usually narrow or if they close the trail system above or below, where they have more spaciousness. The densest network is located in the municipality of Miraflores, due to the topographic characteristics.

\subsection{The Organization of Rural Space and the Community}

As indicated in the historical reconstruction, human life on the slopes of The Najarra was remarkable, given that high-altitude pastures and sheepfolds have been used since the medieval repopulation until the middle of the 20th century, when the decline of the traditional economy took place. The pastures were useful for transhumant merino sheep and goats and cattle from the immediate towns of the Mountains, as summer pastures (Suarez et al., 2007). In the middle of spring the herds of the towns went up to pastures and merino sheep from Extremadura were received. In Miraflores, the sheep, after shearing them for the feast of San Pedro-at the end of June, they went up to the mountains and the barracks in The Najarra or beyond, where they remained until mid-November (Guadalix, 2017: p. 19). The shepherds were for four or five months in flocks. The footprints left in the landscape by the historical activity of the shepherds' life currently remain on the slopes in the form of ruins of huts and sheepfolds. The form of afforestation in the mid-19th century in the Najarra massif, using seedlings made by hand without hardly removing the land, facilitated the preservation of the road system and the imprint of cattle corrals and shepherd's huts, 
built in stone dry. The grazing system in this area of the sierra has not only left remarkable natural values, but also cultural and heritage ones. One of the most important hut and sheepfold concentrations in the area was established in the Najarra massif (Vías, 2001: p. 191). Until the end of the 19th century, thousands of merino sheep from Extremadura spent their summers days in the numerous flocks around the Najarra massif, where more than 15,000 sheep were grazed (Vías, 2014: p. 107). This remarkable pastoral life is related to the Royal cattle herd Segoviana and the establishment of an annual cycle that began in the spring, in mid-June: 1) with the arrival of cattle from Extremadura, 2) the shearing at the foot of the saw, 3) the ascent to the cattle lungs of the ports and 4) the distribution in flocks-where it remained all summer-so that the cattle grazed, an activity that required the calculation of animals per flock. The trails have long been used by humans and nonhumans. Over time, the roads are rationalized in order to reach destinations faster or with less effort (Moor, 2016).

Life in the sheepfolds was austere, marked by loneliness, adverse weather and harsh living conditions. The shepherds' used to make seven-day shifts or relays among themselves to be able to go down to the villages and be with their families whom they had not seen during the long months spent in the Extremadura pastures, and incidentally, to get the necessary supplies. Their sober diet (...) because the rest was provided by livestock "(Vías, 2001: p. 46). This type of traditional life had little change until the 1960s (Martín-Banta \& Martín-López, 2008). Also in the area the cattle moved seasonally from the high-altitude flocks to the lower grazed areas. The shepherds played a relevant and continued role in the urban "discovery" of the Guadarrama, given that they were the inhabitants of the mountains. The shepherds were recently the actors' introducers" of urban athletes and hikers in the Sierra de Guadarrama (Vías, 2001).

Another type of livestock is the cowboy, who until the first snowfall in November remained in the flocks. Each cowboy kept a herd of around a hundred cattle in the flocks established in the passes and meadows near the ports (Vías, 2001: pp. 47-48). Every night they gathered cattle in large stone fences. Field cows coexisted and finally displaced milk cows in the late 20th century (Guadalix, 2017). In parallel, goats and sheep disappear.

According to testimonies of five old livestocks, the life of people related to ranching begins in childhood within the family-it is a job that is learned from childhood-they are jobs that are transmitted between generations and that Often, as has happened historically, they combine different types of livestock. "I started working with my father when I was 12 or 13 years old. Bad activity, little was earned, all day in the field, bad activity, there was no money, it was post-war" (San, bus, Jun_2019). The work has not changed much from its origins until the 1960s. From April to August they went up to the mountain sheepfolds, then led the cattle to the meadows closest to the towns. The work began at dawn and ended at dusk. "In summer you went to the mountains and in winter to warmer places, especially in the area. We went to other places to winter, that is, we went 
outside" (San, bus, Jun_2019). Management has gradually been simplified, with agriculture disappearing, except in orchards near the municipality. Sheep cattle have also disappeared. The management of cattle has been simplified by extending it, with resistant breeds to the mountain, "it is no longer as slave as before", but the difficulties have recently increased due to the competition of uses in the territory with hikers and cyclists. Permanently insists on conflicts with cyclists, for the rights to use trails: "We are a population close to Madrid and they invade us during the weekend. They do not respect us and fences... portages. Private property is respected. Increasingly more" (...) "those from Madrid run over the countryside in disarray, it is a problem of the entire Sierra" (Coll, bus, Jun_2019). The traditional use of the roads disappeared due to afforestation, but some of the roads always continued to be used by ranchers and cattle to access the flocks. "When they repopulated badly, they took away the saw, whoever was in charge, in command, now lost everything, is not managed (...). There was little land, they took away from you, and they couldn't get into it. The roads are not preserved; there is no one to look for it. Everything has been left dead and full of forest. Every day much worse" (San, bus, Jun_2019). "The goatherds protested, but nothing more. They could not graze in these fields" (Baon, bus, Jun_2019). The continuity in the opening of the main historical roads has corresponded in recent decades to the farmers themselves, due to the extensive nature of livestock management, which remains in the bush for a good part of the year. The decrease in free communal pastures due to reforestation and urbanizations complicated traditional livestock management. The gradual decline of extensive livestock farming complicates the opening of some trails, especially where there is no woodland as it is invaded by mountain scrub. "Now there is nothing but weeds, bad esparto. Worthless. Since there is no cattle. Everything is useless. Bad herbs. When there was a lot of cattle he was clean, he raised good herbs" (San, bus, Jun_2019). Local-popular knowledge of the trails can be extinguished by the disappearance of the last ranchers who used them.

In 1915, as Victory described The Najarra in the magazine Peñalara in this way, pointing to an incipient process of rural change: "and we left the top cliffs of La Najarra. Not because it is further away, this mountain is less interesting, so little frequented in winter, ridden by hikers who see it passing through the Morcuera, precisely when it is most beautiful, half covered by the snowy mantle of the sovereign summits" (Victory, 1915: p. 3), and it continues: "but after the spring sun undoes your bloody snows and the summer arrives, the vacationers of the town to which you give shade will contemplate you from the Posada del Rey, from the Cabezuela, from the Fuente of the Teja, and some, undoubtedly, the bravest will climb to your very summit and then have lunch next to your purest waters of the Fuentefría" (Victory, 1915: p. 3). This description points to a seasonal use of the Najarra associated with the beginning of a process of abandonment of the traditional economy and the rise of recreational use. Also to a certain marginality in its geographical context. 


\subsection{Wild Fauna, Organization of Space and Rural Life}

The practice of livestock activity and its territorial organization was conditioned by the existence of wild fauna and especially wolves, a species that was still very abundant during the 19th century. In this sense, during the first half of the 19th century there are numerous instructions on wolf hunting prizes, for their excessive number and the problem for livestock (Orders of June 2, 1824, ARCM, box 7. Miraflores Fund of the Saw). In fact, the use of shotguns was authorized to the shepherds and scattered neighbors, due to the presence of wolves in the year 1824 (Document December 22, 1824, ARCM, box 7. Miraflores of the Sierra Fund). This must have been a permanent and not just a specific problem, as shown by the resolutions of the mid-nineteenth century on the extermination of wolves, foxes and other harmful animals and the payments for killing each type of piece (Resolution 6 November 1885. Accounts of the Mesta gang, ARCM, box 9. Miraflores of the Sierra Fund). In 1824 the mayor of the Mesta gang in the town of Miraflores of the Sierra himself asked for an award for having killed six cubs in the municipality of Manzanares (Written April 27, 1824 to the President of the Mesta, ARCM, box 7. Miraflores of the Sierra Fund). The hunter nicknamed "Francachela" (who lived between 1826 and 1911) who hunted up to 219 wolves in the Najarra massif of Miraflores of the Sierra (Suarez et al., 2007) is remembered with his own name. Currently it has a monument in the village that symbolizes the fight against the wolf in the 19th century. The last great shells were produced towards the end of the second decade of the 20th century (Vías, 2001: p. 49). Still in June 1917, in the sheepfolds of the study area a pack of wolves killed 70 sheep, news that appeared in the Madrid press (Hungry Wolves, El Mundo newspaper, June 28, 1917). The abundance of wolves is also manifested in toponymy-ej. Col of Pedro of the Lobos, at the western end of the Najarra massif.

\section{Conclusion}

This contribution derives from a micro-level interpretation of the intersections between rural, cultural and historical geography in the study of local historical trails.

The occupation of the territory occurs in a way that coincides with the medieval repopulation of these lands, which for many years were frontier spaces between the Christian and Muslim worlds. Since the fourteenth century there has been an organized occupation of the space where livestock activity has acquired a leading role. From this stage there are numerous lawsuits for boundaries and land rights between neighbors. Around Miraflores of the Sierra there were pastures fenced with stone walls for their protection and restricted use, while the rest of the municipal terms are free pastures. The pastoral life little changed until the middle of the 20th century. The shepherds used to be in the flocks for 4 or 5 months. The practice of livestock activity traditionally coexisted with wildlife and the wolf. 
In this historical context, the Najarra road system is complex and hierarchical between 1200 and 1900 meters for the use of the slope and the connection of the different sheepfolds. It is a planned and in no way spontaneous design, suggesting a remarkable knowledge of space. It also reflects a micro organization based on three dimensions: physical, socioeconomic, and legal. The traditional use of the road system disappeared with reforestation, but some roads continue to be used for access to sheepfolds. The progressive disappearance of extensive livestock farming complicates the continuity of some trails, which are invaded by mountain scrub. In other cases there are conflicts for new users such as cyclists or walkers.

\section{Conflicts of Interest}

The author declares no conflicts of interest regarding the publication of this paper.

\section{References}

Ansola, A. (2018). Un ensayo metodológico de caminería y geografía históricas en el valle de Lamasón (Cantabria). Cuadernos Geográficos, 57, 200-221. https://doi.org/10.30827/cuadgeo.v57i3.6226

Baker, A. (2003). Geography and History. Bridging the Divide. Cambridge: Cambridge University Press. https://doi.org/10.1017/CBO9780511615818

Brady, E. (2006). The Aesthetics of Agricultural Landscapes and the Relationship between Humans and Nature. Ethics, Place and Environment, 9, 1-19. https://doi.org/10.1080/13668790500518024

Butlin, R. (1993). Historical Geography. Through the Gates of Space and Time. London: Edward Arnold.

Clark, G. (1997). The Educational Value of the Rural Trail: A Short Walk in the Lancashire Countryside. Journal of Geography in Higher Education, 21, 349-362. https://doi.org/10.1080/03098269708725441

Cloke, P. (2016). Rural Landscapes. In N. Johnson, R. Schein, \& J. Winders (Eds.), The Wiley Blackwell Companion to Cultural Geography (pp. 225-237). Oxford: Wiley \& Sons. https://doi.org/10.1002/9781118384466.ch21

Duffy, P. (2009). Historical Geographies, Rural. In R. Kitchin, \& N. Thrift (Eds.), International Encyclopedia of Human Geography (Vol. 5, pp. 136-145). Amsterdam: Elsevier. https://doi.org/10.1016/B978-008044910-4.00392-8

Edensor, T. (2000). Walking in the British Countryside: Reflexivity, Embodied Practices and Ways to Escape. Body \& Society, 6, 81-106. https://doi.org/10.1177/1357034X00006003005

Hardy, D. (1988). Historical Geography and Heritage Studies. Area, 20, 333-338.

Johnston, R. (1983). Philosophy and Human Geography. An Introduction to Contemporary Approaches. London: Edwards Arnold.

Kolen, J., \& Renes, J. (2015). Landscape Biographies and Biographies of Landscapes. In J. Kolen, J. Renes, \& R. Hermans (Eds.), Landscape Biographies. Geographical, Historical and Archeological Perspectives on the Production and Transmission of Landscapes (pp. 22-47). Amsterdam: Amsterdam University Press.

https://doi.org/10.5117/9789089644725 
Lorimer, H. (2011). Walking: New Forms and Spaces for Studies of Pedestriansm. In T. Cresswel, \& P. Merriman (Eds.), Geographies of Mobilities: Practices, Spaces, Subjects (pp. 19-34). Farnham: Ahsgate.

Lorimer, H. (2015). Preface. In J. Kolen, J. Renes, \& R. Hermans (Eds.), Landscape Biographies. Geographical, Historical and Archeological Perspectives on the Production and Transmission of Landscapes (pp. 17-20). Amsterdam: Amsterdam University Press. https://doi.org/10.1515/9789048517800-002

MacFarlane, R. (2017, original 2012). Las viejas sendas. Valencia, Pre-textos.

Massey, D. (1995). Places and Their Pasts. History Workshop Journal, 39, 182-192. https://doi.org/10.1093/hwj/39.1.182

Merriman, P., \& Jones, R. (2017). Nations, Materialities and Affects. Progress in Human Geography, 41, 600-617. https://doi.org/10.1177/0309132516649453

Moor, R. (2016). On Trails: An Exploration. New York: Simon and Schuster.

Paniagua, A. (2017). The (Lost) Life of a Historic Rural Route in the Core of Guadarrama Mountains, Madrid (Spain). A Geographical Perspective. Landscape History, 38, 81-94. https://doi.org/10.1080/01433768.2017.1322272

Post, Ch. (2013). Heritage, Amenity, and the Changing Landscape of the Rural American West. Journal of Cultural Geography, 30, 328-355. https://doi.org/10.1080/08873631.2013.828484

Price, P. (2016). Place. In N. Johnson, R. Schein, \& J. Winders (Eds.), The Wiley Blackwell Companion to Cultural Geography (pp. 118-129). Oxford: Wiley \& Sons. https://doi.org/10.1002/9781118384466.ch13

Riesenweber, J. (2008). Landscape Preservation and Cultural Geography. In R. Longstreth, \& S. Boyle (Eds.), Cultural Landscape: Balancing Nature and Heritage in Preservation Practice (pp. 23-34). Minneapolis, MN: University of Minnesota Press.

Rose, M., \& Wylie, J. (2011). Landscape-Part II. In J. Agnew, \& J. Duncan (Eds.), The Wiley-Blackwell Companion to Human Geography (pp. 221-235). Oxford: Wiley-Blackwell. https://doi.org/10.1002/9781444395839.ch14

Sauer, C. (1941). Foreword to Historical Geography. Annals of the Association of American Geographers, 31, 1-24. https://doi.org/10.1080/00045604109357211

Schein, R. (2010). Cultural Landscapes. In B. Gomez, \& J. P. Jones III (Eds.), Research Methods in Geography. A Critical Introduction (pp. 222-240). Chichester: Wiley-Blackwell.

Strohmayer, U. (2014). Historical Geographical Traditions. In J. Morrisey, D. Nalley, U. Strohmayer, \& Y. Whelan (Eds.), Key Concepts in Historical Geography (pp. 269-279). London: Sage.

Swaffield, S., \& Primdahl, J. (2014). Editorial: Pathways towards Local Scale Policy Integration in Agricultural Landscapes. Landscape Research, 39, 101-106. https://doi.org/10.1080/01426397.2014.889461

Taylor, M. (2013). International Overview of Cultural Routes: Research and Stewardship. Historic Environment, 2, 16-28.

Waitt, G., Gill, N., \& Head, L. (2009). Walking Practice and Suburban Nature-Talk. Social and Cultural Geography, 10, 41-60. https://doi.org/10.1080/14649360802553186

Wheeler, R. (2017). Local History as Productive Nostalgia? Change, Continuity an Sense of Place in Rural England. Social \& Cultural Geography, 18, 466-486. https://doi.org/10.1080/14649365.2016.1189591

Whelan, Y. (2014). Conceptualizing Cultural Heritage. In J. Morrisey, D. Nalley, U. Strohmayer, \& Y. Whelan (Eds.), Key Concepts in Historical Geography (pp. 172-181). London: Sage. 


\section{Local References}

Apuntes (1933). Apuntes para la historia de la villa de Miraflores de la Sierra por un veraneante. Madrid: Imp. L. Rubio.

Asenjo, M. (1986). Sociedad urbana y repoblación de las tierras de Segovia, al Sur de la Sierra de Guadarrama. La España Medieval, 5, 125-149.

Colmenarejo, F. et al. (2012). Chozas de la Sierra. La construcción del espacio del agua en Soto del Real (Madrid). Madrid: Equipo Arqueologia A.

Consejería de Política Territorial (1987). Normas subsidiarias de planeamiento municipal (2 vols). Madrid: Comunidad de Madrid.

Fernández Ibero, F. (1953). Miraflores de la Sierra (historia del antiguo Porquerizas) (144 p). Madrid.

Fernández Suarez, R. (1995). La institución municipal en la historia de Miraflores de la Sierra. Territorio y Cultura (160 p). Madrid: Ayuntamiento de Miraflores.

González Guadalix, J. (1994). Miraflores de la Sierra (159 p). Madrid: Centreur.

Guadalix, F. (2017). Miraflores. Paseando por sus recuerdos (257 p). Tres Cantos: PuntoDidot.

López, L. (2002). 250 años recorriendo la Sierra de Guadarrama. Madrid: Ed. Werner-Cosmos.

Martín-Banta, F., \& Martín-López, J. (2008). La vida tradicional en la Sierra de Madrid. Bustarviejo en el Pasado. Bustarviejo (Madrid): Asociación Cultural El Bustar.

Menéndez Pidal, R. (1960). Repoblación y tradición en la cuenca del Duero, Madrid, CSIC. La Enciclopedia lingüística hispánica, Tomo I, LXIV.

Nieto, J. (2017). Historia social de la Sierra Norte (202 p). Madrid: LiberFactory.

Suarez, A., Suarez, B., \& Suarez, F. (2007). Historias menudas del Guadarrama. Madrid: Art \& Press.

Vías, J. (2001). Memorias del Guadarrama. Historia del descubrimiento de una montaña. Madrid: Ed. La Librería.

Vías, J. (2014). Parque Nacional de la Sierra de Guadarrama. Guía para contemplar su paisaje. Madrid: La Librería.

Victory, A. (1915). La Najarra. Revista Ilustrada de Alpinismo, tomo II, 13-24.

\section{Historical Archive References}

ARCM

Leyes de la Mesta, 1609. ARCM, caja 7. Fondo Miraflores de la Sierra.

Ordenanzas, cuentas y asuntos de la Mesta. Compilación de documentos. 1724-1728. ARCM, caja 8.6 y 8.7. Fondo Miraflores de la Sierra.

Real Cédula de S.M. y Señores del Consejo por el aval se subroga en los corregidores y alcaldes mayores del Reyno, en concepto de subdelegados del presidente del honrado concejo de la Mesta, las funciones, jurisdicción y facultades que antes exercían los alcaldes mayores entre ganaderos de mestas y cañadas, en los términos que se expresan en la instrucción inserta. 1796. Alcalá, Imprenta de don Isidro López. ARCM, caja 7. Fondo Miraflores de la Sierra.

Ordenes sobre la cuadrilla de la Mesta-diversos años-ARCM, caja 8. Fondo Miraflores de la Sierra.

Juntas de Cuadrilla, Matricula, nombramientos. Diversos años, Matrícula año 1891. ARCM, caja 8, Fondo Miraflores de la Sierra. 
Escrito 27 de abril de 1824 al Presidente de la Mesta, ARCM, caja 7. Fondo Miraflores de la Sierra.

Órdenes de 2 de junio 1824, ARCM, caja 7. Fondo Miraflores de la Sierra.

Escrito de la Presidencia de la Asociación General de Ganadería dirigido al Alcalde de Miraflores de la Sierra. Presidente de la cuadrilla de ganaderos de su distrito, noviembre 15 de 1839. ARCM, caja 8, 8.1. Fondo Miraflores de la Sierra.

Presidencia de la Asociación General de Ganadería, noviembre 15 de 1839. ARCM, caja 8, 8.1. Fondo Miraflores de la Sierra.

Ordenes sobre la Mesta de las intrusiones de los cordeles de varios años Mesta: ordenes e informes sobre el asunto del Juncal y cierre del Señor. Años 1847-50 y 51, y 52. ARCM, caja 8, 8.3. Fondo Miraflores de la Sierra.

Resolución 6 noviembre 1885 Cuentas de la cuadrilla de la Mesta, ARCM, caja 9. Fondo Miraflores de la Sierra.

$A H N$

Escrito del visitador de la Asociación Nacional de Ganaderos "Sobre que en el término de Miraflores de la Sierra se hallan roturadas las servidumbres y se exigen contentas a los ganaderos por pasar con sus ganados por las servidumbres". Miraflores de la Sierra. Madrid. 1881. AHN Diversos-Mesta, 885, exp. 3.

$B N$

Biblioteca Nacional. 1607. Carta de privilegio y confirmación del villazgo de galapagar, Porquerizas y Guadalix. España. Rey (1516-1556. Carlos I).

Biblioteca Nacional. 1524a. Provisión del Duque del Infantado de las Villas de Guadalix y Porquerizas. Duque del Infantado 1461-1531.

Biblioteca Nacional. 1524b. Provisión del Duque del Infantado en que hizo villa al lugar de Porquerizas. Duque del Infantado 1461-1530.

Archives and libraries consulted

AHN. Archivo Histórico Nacional.

BN. Biblioteca Nacional.

ARCM Archivo Regional de la Comunidad de Madrid.

BRCM Biblioteca Regional de la Comunidad de Madrid.

Local libraries of Manzanares el Real, Soto del Real, Miraflores de la Sierra and Bustarviejo. 